\title{
Synthesis of vinyl sulfides using glycerol as a recyclable solvent
}

\author{
Eder J. Lenardão, Márcio S. Silva, Renata G. Lara, Júnior M. Marczewski, \\ Maraisa Sachini, Raquel G. Jacob, Diego Alves, and Gelson Perin* \\ Instituto de Química e Geociências, LASOL, Universidade Federal de Pelotas, UFPel, P.O. Box \\ 354, 96010-900 Pelotas, RS, Brazil \\ E-mail: gelson_perin@ufpel.edu.br
}

\begin{abstract}
A new, clean, and efficient protocol is described for the hydrothiolation of terminal alkynes promoted by $\mathrm{KF} / \mathrm{Al}_{2} \mathrm{O}_{3}$, using glycerol as recyclable solvent. This improved method furnishes selectively the corresponding anti-Markovnikov vinyl sulfides in good to excellent yields starting from terminal alkynes and aliphatic or aromatic thiols. The irradiation with microwaves facilitated the procedure and accelerates the reaction. The catalytic system and the glycerol can be re-used up to four times without previous treatment, and with comparable activity.
\end{abstract}

Keywords: Microwave-assisted, hydrothiolation, glycerol, KF/alumina

\section{Introduction}

Vinyl sulfides are present in natural occurring compounds such as griseoviridin and benzylthiocredillidone, with important biological activities. ${ }^{1,2}$ The first compound is a type A streptogramin antibiotic, firstly isolated from Streptomyces graminofaciens, ${ }^{1}$ while benzylthiocredillidone is a yellow pigment isolated from the brightly red colored sponge Crella spinulata. $^{2}$ Besides, vinyl sulfides are a very useful tool in organic reactions, acting as key intermediate in organic synthesis. ${ }^{3}$ Various methods are described for the preparation of vinyl sulfides and the most common protocols involve the addition of thiol, or the respective anions, to terminal or internal alkynes. ${ }^{4-10}$ Most of the described methods make use of toxic organic solvents and are catalyzed by transition-metals ${ }^{4}$ or promoted by base. ${ }^{5}$ More recently, some improvements on selective preparation of vinyl sulfides have been described. ${ }^{6-11}$ These comprise the use of catalytic phenylselenenyl bromide, ${ }^{6}$ nickel, ${ }^{7}$ gold ${ }^{8}$ or native silica nanoparticle ${ }^{9}$ under solvent-free conditions, $\beta$-cyclodextrin in the presence of water and acetone ${ }^{10}$ or under catalystfree conditions. ${ }^{11}$ In recent years, the use of potassium fluoride supported on alumina $\left(\mathrm{KF} / \mathrm{Al}_{2} \mathrm{O}_{3}\right)$ as a green catalytic system for a number of transformations has been increased. ${ }^{12}$ By using $\mathrm{KF} / \mathrm{Al}_{2} \mathrm{O}_{3}$, the products can be easily isolated by filtration and the generation of large amounts of 
salts at the end of the synthesis, as well as the use of stoichiometric strong bases, can be avoided. On the other hand, the development of green solvents from renewable resources has gained much interest recently, because of the extensive use of solvents in almost all of the chemical industry, and of the predicted disappearance of fossil oil. ${ }^{13}$ The wanted characteristics for a green solvent include no flammability, high availability, obtaining from renewable sources and biodegradability. ${ }^{14}$ Thus, the use of glycerol as a promising medium for organic reactions was recently demonstrated by $\mathrm{us}^{15,16}$ and others. ${ }^{17-21}$ These include Pd-catalyzed Heck ${ }^{17-19}$ and Suzuki ${ }^{17}$ cross-couplings, base ${ }^{18}$ and acid ${ }^{15}$ promoted condensations, catalytic hydrogenation ${ }^{19,20}$ and asymmetrical reduction. ${ }^{19}$

More recently, we have described several efficient approaches using $\mathrm{KF} / \mathrm{Al}_{2} \mathrm{O}_{3} .^{22,23}$ As a continuation of our studies we report herein the full results of the hydrothiolation of alkynes 1 using $\mathrm{KF} / \mathrm{Al}_{2} \mathrm{O}_{3}$ without any solvent (Method $\mathrm{A}$ ), ${ }^{22}$ as well as the use of glycerol as recyclable solvent for this reaction (Scheme 1).

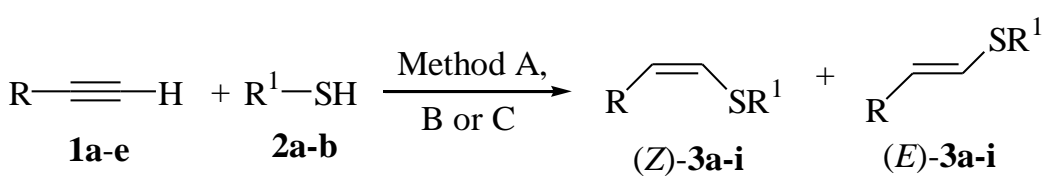

\section{Scheme 1}

\section{Results and Discussion}

In a recent communication, we described the optimum conditions to perform the solvent-free hydrothiolation of several alkynes using $\mathrm{KF} / \mathrm{Al}_{2} \mathrm{O}_{3}$ as solid catalyst. ${ }^{22}$ It was found that the best conditions for the hydrothiolation consists in stirring a mixture of $\mathbf{1 a}(2 \mathrm{mmol})$ and $\mathbf{2 a}(1 \mathrm{mmol})$ in presence of $0.08 \mathrm{~g}(51 \mathrm{~mol} \%)$ of $\mathrm{KF} / \mathrm{Al}_{2} \mathrm{O}_{3}(40 \%)$ at gently heating $\left(60{ }^{\circ} \mathrm{C}\right)$ and under $\mathrm{N}_{2}$ atmosphere, (Table 1, entry 1).

Despite the good yields and generality of the solvent-free protocol described above, the method is restricted to thiols and/or alkynes that are liquid at room temperature or with low melting points. To circumvent this limitation, but maintaining our focal point, i.e., a cleaner procedure for the hydrothiolation, we decide to expand the studies using of a recyclable solvent. Thus, glycerol, a renewable feed-stock which is easily available as a co-product in biodiesel production, was studied as a solvent in this reaction (Method B, Table 1). The best yields were obtained when a mixture of the alkyne $1(1.0 \mathrm{mmol})$ and the thiol $2(1.0 \mathrm{mmol})$ and $\mathrm{KF} / \mathrm{Al}_{2} \mathrm{O}_{3}$ $(40 \%, 0.08 \mathrm{~g})$ in glycerol $(3 \mathrm{~mL})$, was vigorously stirred at $90{ }^{\circ} \mathrm{C}$ for $2-6$ hours (Method B, Table 1). Thus, by using glycerol as solvent, benzenethiol $\mathbf{2 a}$ reacted with propargyl alcohol 1a to afford the respective adduct $\mathbf{3 b}$ in $80 \%$ yield after stirring at $90{ }^{\circ} \mathrm{C}$ for 2 hours, a $25 \%$ increasing in yield, compared with the solvent-free protocol (Table 1, entries 1 and 2). This augmentation in yield was observed for all the tested examples, indicating that glycerol is a very good solvent for 
this reaction. Aiming to reduce the reaction time, the mixture in glycerol was irradiated with focused microwaves at the same temperature $\left(90{ }^{\circ} \mathrm{C}\right.$, Method $\left.\mathrm{C}\right)$. It was observed complete consume of thiol 1a after irradiation for 10 min and 3a was obtained in $95 \%$ yield (Table 1, entry 3).

Table 1. Hydrothiolation of alkynes using $\mathrm{KF} / \mathrm{Al}_{2} \mathrm{O}_{3}$ and glycerol

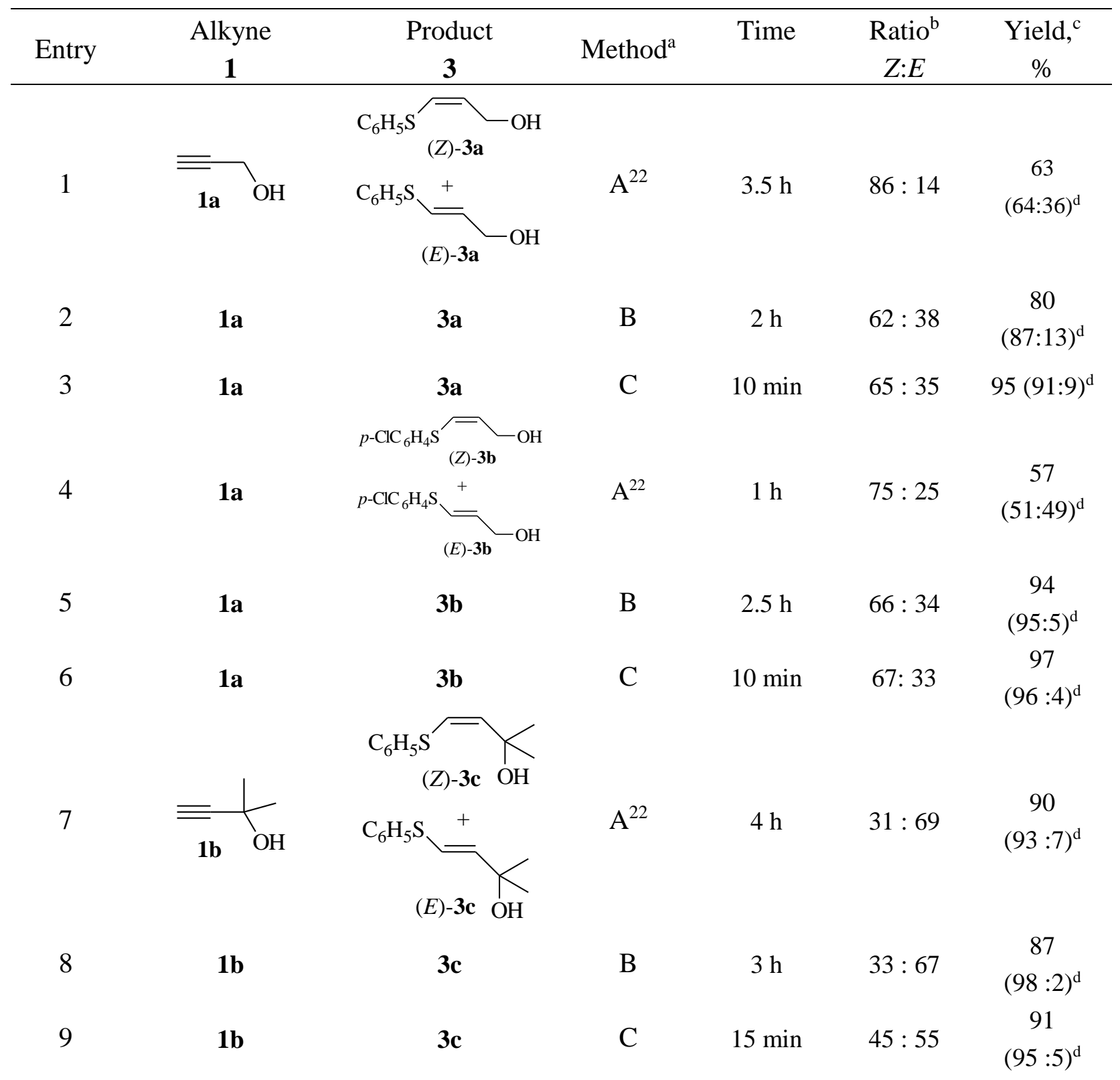


10<smiles>C#CC1(O)CCCCC1</smiles>

$11 \quad \mathbf{1 c}$

12

13

$1 c$

14

15

16

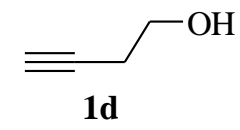

17

18

19

1d
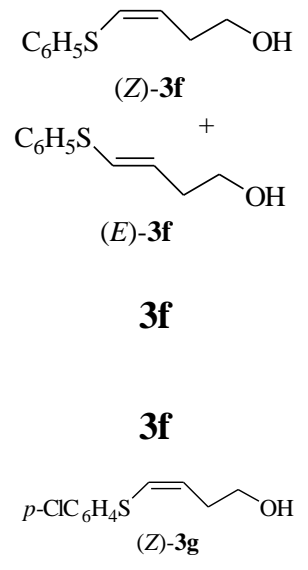

$\mathrm{A}^{22}$

B

C
B

C

$\mathrm{A}^{22}$

B

$\mathrm{C}$
$3 \mathrm{~h}$

$13: 87$

56

$(94: 6)^{\mathrm{d}}$

75

$(84: 16)^{\mathrm{d}}$

81

$(82: 18)^{\mathrm{d}}$

\section{$5 \mathrm{~h}$}

$20: 80$

63

$(93: 7)^{\mathrm{d}}$

78 $(98: 2)^{\mathrm{d}}$

82 $(99: 1)^{\mathrm{d}}$

62

$2 \mathrm{~h}$

$53: 47$

$(92: 8)^{\mathrm{d}}$

84 $(85: 15)^{\mathrm{d}}$

72 $(91: 9)^{\mathrm{d}}$ $\begin{array}{llcc}\mathrm{A}^{22} & 2 \mathrm{~h} & 50: 50 & 55 \\ & & & (54: 46)^{\mathrm{d}}\end{array}$

B $\quad 2 \mathrm{~h} \quad 52: 48$

80 $(92: 8)^{\mathrm{d}}$ 79 $(87: 13)^{\mathrm{d}}$ 


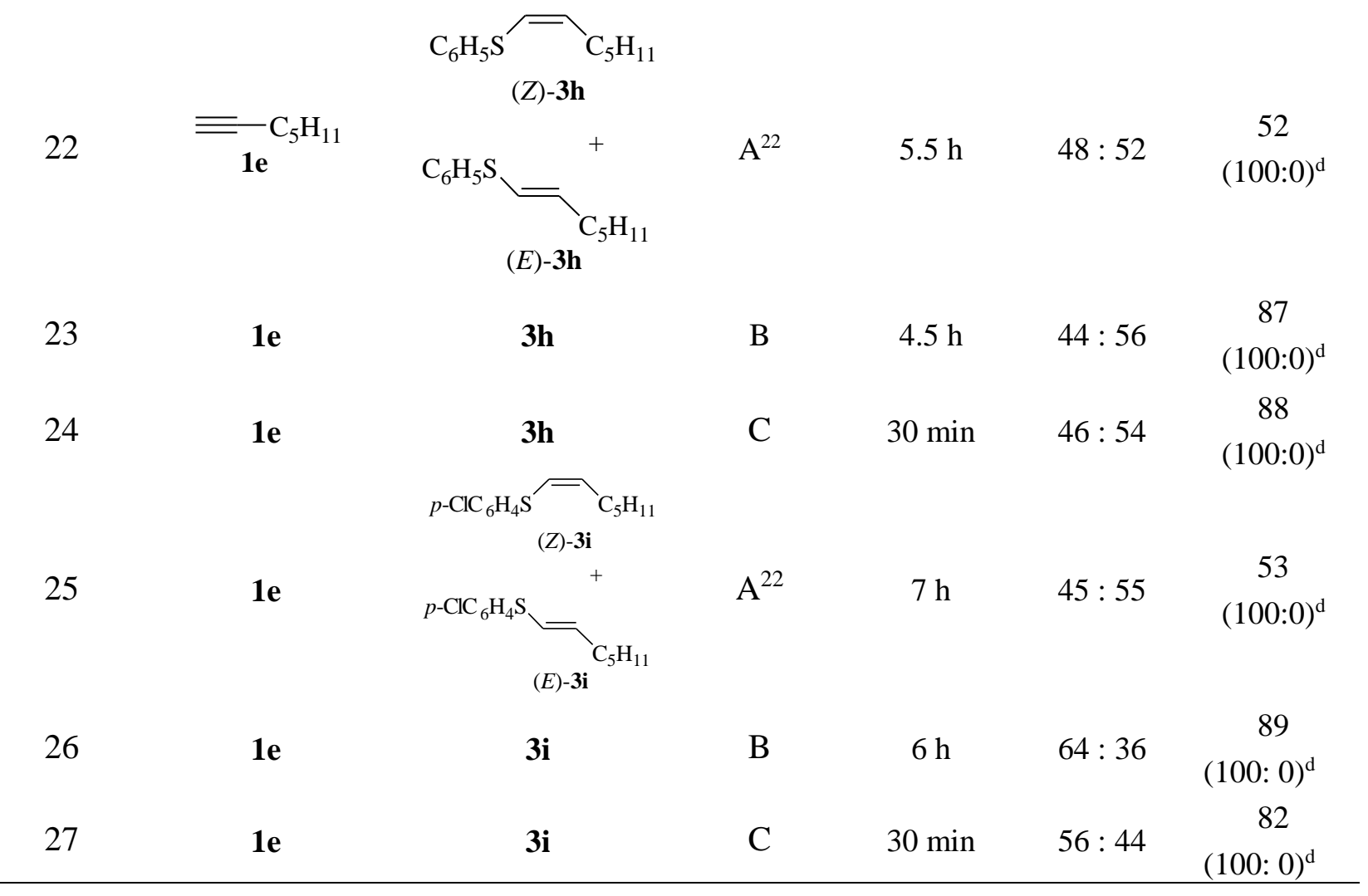

${ }^{\text {a Method A. }}{ }^{22}$ The experiments were performed at $60{ }^{\circ} \mathrm{C}$. Method B: The experiments were performed at $90{ }^{\circ} \mathrm{C}$ using glycerol $(3 \mathrm{~mL} / \mathrm{mmol})$ as solvent. Method C: The experiments were performed using glycerol and MW at $90{ }^{\circ} \mathrm{C}$. ${ }^{b}$ Determined by ${ }^{1} \mathrm{H}$ NMR of the crude reaction mixture and confirmed after isolation of the mixture of formed isomers. ${ }^{c}$ Yields of the mixture of isomers obtained by column chromatography eluting with hexanes $\mathbf{3 h - 3 i}$ or with hexane/ethyl acetate 3a-3g (98:2). ${ }^{\mathrm{d}}$ The regioselectivity of the hydrothiolation (the ratio of anti-Markovnikov to Markovnikov adducts).

Concerning the stereochemistry of products, for all the studied examples, the antiMarkovnikov adduct 3 were obtained in higher amount than the Markovnikov one. The results depicted in Table shown that glycerol was an excellent solvent, affording the vinyl sulfides in better yields and with a very good selectivity for the anti-Markovnikov adducts, compared to the solvent-free protocol. This higher selectivity is evident for the alkynes $\mathbf{1 a}$ and 1d (Table 1, entries 1, 3, 4, 6, 19 and 21).

To check the efficacy of this method, a reuse study of the glycerol/ $/ \mathrm{KF} / \mathrm{Al}_{2} \mathrm{O}_{3}$ medium was carried out for the model reaction involving propargyl alcohol 1a and benzenethiol 2a. After completion of the hydrothiolation of 1a, the product was extracted simply by washing the reaction mixture with three portions of hexanes. The remained lower phase containing glycerol/KF/ $/ \mathrm{Al}_{2} \mathrm{O}_{3}$ was then recovered, dried under vacuum and reused for further reactions. Fortunately, the catalytic system maintained a good level of efficiency after being reused by five times $(95 \%, 94 \%, 90 \%, 89 \%$ and $80 \%$ yield of 3a). However, after the fifth reuse, the catalytic 
system loose drastically its activity, affording 3a in only 53\% and $42 \%$ yields after successive cycles.

A tentative mechanism for explaining the regiochemistry of the hydrothiolation is depicted in Scheme 2. The formation of the Markovnikov adduct starting from propargyl alcohols suggests that the transition state $\mathbf{5}$ can be involved, while the formation of the anti-Markovnikov adduct involves the intermediate 4. This proposition is corroborated by the increasing in the ratio anti-Markovnikov: Markovnikov adduct when glycerol is used as solvent, via a transition state like $\mathbf{4 b}$.

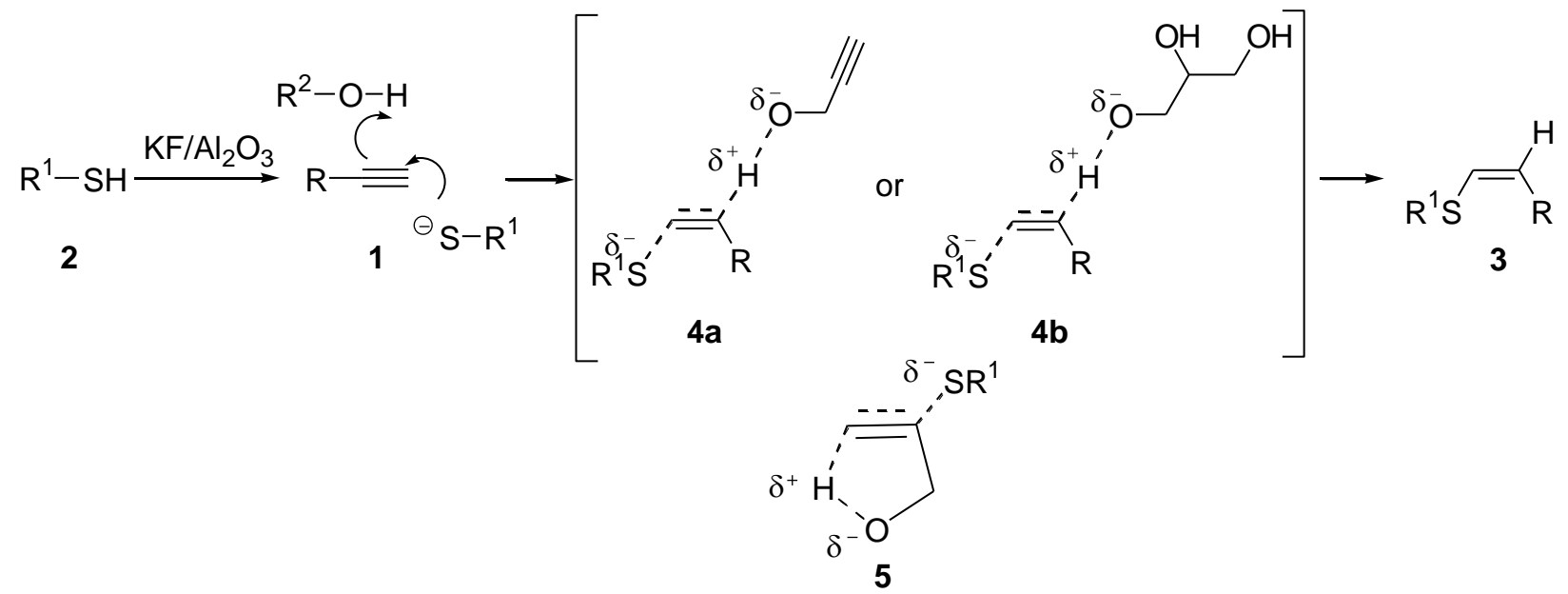

Scheme 2

\section{Conclusions}

In summary, an efficient and clean protocol was developed for the selective synthesis of vinyl sulfides using $\mathrm{KF} / \mathrm{Al}_{2} \mathrm{O}_{3}$ and glycerol as recyclable solvent. The reaction proceeds easily and the products were obtained in good to excellent yields. Glycerol was successfully used as a renewable, non-toxic, and recyclable solvent, opening new possibilities for future applications of glycerol in green and sustainable chemistry. The procedure is very simple and the solvent/catalyst system can be directly re-used. The use of microwaves accelerates the reaction with comparable yields in most of examples. Applications of glycerol in other organic reactions are ongoing in our laboratory. 


\section{Experimental Section}

General. The ${ }^{1} \mathrm{H}$ - and ${ }^{13} \mathrm{C}$ - NMR spectra of $\mathrm{CDCl}_{3}$ solutions were recorded with a $200 \mathrm{MHz}$ or a $400 \mathrm{MHz}$ spectrometer (Bruker DPX), as noted. Spectra were recorded in $\mathrm{CDCl}_{3}$ solutions. Chemical shifts are reported in ppm, referenced to the solvent peak of $\mathrm{CDCl}_{3}$ (for ${ }^{13} \mathrm{C}$ spectra) or tetramethylsilane (TMS, for ${ }^{1} \mathrm{H}$ ) as the internal reference. Data are reported as follows: chemical shift $(\delta)$, multiplicity, coupling constant $(J)$ in Hertz and peak intensity. Low Resolution Mass Spectra (LRMS, EI) were obtained at $70 \mathrm{eV}$ with a Hewlett Packard EM/CG HP-5988A spectrometer. High-Resolution Mass Spectra: HR-ESI-MS were performed in the positive mode (UltrOTOF-Q system, version 1.10, Bruker Daltonics, MA, USA). Merck's silica gel (230-400 mesh) was used for flash chromatography. All microwave tests were conducted using a CEM Discover, mode operating systems working at $2.45 \mathrm{GHz}$, with a power programmable from 1 to $300 \mathrm{~W}$.

General preparation of alumina- supported potassium fluoride. ${ }^{22-24}$ To a $100 \mathrm{~mL}$ beaker was added alumina (6.0 g of $\mathrm{Al}_{2} \mathrm{O}_{3}$ 90, 0.063-0.200 mm, Merck), KF.2 $\mathrm{H}_{2} \mathrm{O}(5.2 \mathrm{~g})$ and water (10 $\mathrm{mL}$ ). The suspension was stirred for $1 \mathrm{~h}$ at $65^{\circ} \mathrm{C}$, dried at $80{ }^{\circ} \mathrm{C}$ for $1 \mathrm{~h}$ and for an additional $4 \mathrm{~h}$ at $300{ }^{\circ} \mathrm{C}$ in an oven and then cooled in a desiccator. The content of $\mathrm{KF}$ is about $40 \%(\mathrm{~m} / \mathrm{m})$.

\section{General procedure for the synthesis of vinyl sulfides 3}

Method A. ${ }^{22}$ To a mixture of appropriate alkyne 1 (2 mmol) and thiol 2 (1 mmol) under $\mathrm{N}_{2}$ atmosphere, $\mathrm{KF} / \mathrm{Al}_{2} \mathrm{O}_{3}(0.08 \mathrm{~g}$, obtained as described above) was added at room temperature. Then, the temperature was slowly raised to $60{ }^{\circ} \mathrm{C}$. The reaction progress was followed by TLC. After consuming the starting materials (see Table 1), the crude product was filtered off the solid supported catalyst by washing with ethyl acetate $(10 \mathrm{~mL})$. The solvent was evaporated under reduced pressure and the residue was purified by column chromatography over silica gel eluting with hexanes 3h-3i or with hexane/ethyl acetate 3a-3g (98:2), yielding the products, according Table 1.

Method B. To a mixture of appropriate alkyne 1 (1 mmol) and thiol 2 (1 mmol) in glycerol (3 $\mathrm{mL})$ under stirring and $\mathrm{N}_{2}$ atmosphere, was added $\mathrm{KF} / \mathrm{Al}_{2} \mathrm{O}_{3}(0.08 \mathrm{~g})$ at room temperature. Then, the temperature was slowly raised to $90{ }^{\circ} \mathrm{C}$. The reaction progress was followed by TLC. After consuming the starting materials (see Table 1), the product was extracted from the glycerol by washing the mixture with hexanes $(3 \times 5 \mathrm{~mL})$. The hexanes were evaporated under reduced pressure and the residue was purified according to that described in Method A.

Method C. To a mixture of appropriate alkyne 1 (1 mmol) and thiol 2 (1 mmol) in glycerol (3 $\mathrm{mL})$ under stirring and $\mathrm{N}_{2}$ atmosphere, was added $\mathrm{KF} / \mathrm{Al}_{2} \mathrm{O}_{3}(0.08 \mathrm{~g})$ at room temperature in a 10 $\mathrm{mL}$ glass tube. The vessel was then sealed with a septum, placed into the microwave cavity and irradiated with stirring at $90{ }^{\circ} \mathrm{C}$ for the time given in Table 1 . After allowing the mixture to cool to room temperature, the reaction vessel was opened and the product was purified according to described in Method A. The remaining mixture of glycerol and $\mathrm{KF} / \mathrm{Al}_{2} \mathrm{O}_{3}$ was re-used up to 7 
times by the simple addition of more thiol and alkyne to the remaining mixture in the reaction vessel. Spectral data of vinyl sulfides prepared are listed below.

3-(Phenylthio)prop-2-en-1-ol (3a). ${ }^{25}{ }^{1} \mathrm{H}$ NMR (400 MHz, $\left.\mathrm{CDCl}_{3}\right) \delta Z$ isomer: 7.21-7.42 (m, $5 \mathrm{H}) ; 6.35(\mathrm{dt}, J 9.2$ and 1.2, $1 \mathrm{H}) ; 5.96(\mathrm{dt}, J 9.2$ and 6.6, $1 \mathrm{H}) ; 4.37(\mathrm{dd}, J 6.6$ and 1.2, 2H); 1.92 (broad s, $1 \mathrm{H})$; $E$ isomer: 7.21-7.42 (m, 5H); $6.46(\mathrm{dt}, J 15.6$ and 1.2, $1 \mathrm{H}) ; 5.95$ (dt, $J 15.6$ and $6.8,1 \mathrm{H}) ; 4.20(\mathrm{dd}, J 6.8$ and 1.2, 2H); 1.92 (broad s, 1H); Markovnikov adduct: 7.21-7.42 (m, $5 \mathrm{H}) ; 5.57(\mathrm{~s}, 1 \mathrm{H}) ; 5.24(\mathrm{~s}, 1 \mathrm{H}) ; 4.16(\mathrm{~s}, 2 \mathrm{H}) ; 1.92($ broad s, $1 \mathrm{H})$.

3-(4-Chlorophenylthio)prop-2-en-1-ol (3b). ${ }^{1} \mathrm{H}$ NMR $\left(400 \mathrm{MHz}, \mathrm{CDCl}_{3}\right) \delta Z$ isomer: 7.26-7.37 $(\mathrm{m}, 4 \mathrm{H}) ; 6.29(\mathrm{dt}, J 9.2$ and $1.2,1 \mathrm{H}) ; 5.99(\mathrm{dt}, J 9.2$ and $6.4,1 \mathrm{H}) ; 4.36(\mathrm{dd}, J 6.4$ and $1.2,2 \mathrm{H})$; 1.63 (broad s, $1 \mathrm{H}) ;{ }^{13} \mathrm{C}$ NMR $\left(50 \mathrm{MHz}, \mathrm{CDCl}_{3}\right) \delta 63.9,125.5,127.8,129.1,132.8,133.5,170.3$; $E$ isomer: 7.26-7.37 (m, 4H); $6.41(\mathrm{dt}, J 15.2$ and 1.2, $1 \mathrm{H}) ; 5.97(\mathrm{dt}, J 15.2$ and 5.6, $1 \mathrm{H}) ; 4.21$ $(\mathrm{dd}, J 5.6$ and 1.2, 2H); 1.88 (broad s, $\left.1 \mathrm{H}) ;{ }^{13} \mathrm{C} \mathrm{NMR} \mathrm{(50} \mathrm{MHz,} \mathrm{CDCl}_{3}\right) \delta 65.1,118.0,128.4$, 129.2, 132.4, 134.0, 169.9; Markovnikov adduct: 7.26-7.37 (m, 4H); 5.60 (s, 1H); 5.25 (s, 1H); 4.15 (s, 2H); 1.64 (broad s, 1H); ${ }^{13} \mathrm{C}$ NMR $\left(50 \mathrm{MHz}, \mathrm{CDCl}_{3}\right) \delta 60.8,125.9,129.0,130.5,131.4$, 133.3, 170.4; MS m/z (rel. int., \%) $Z$ isomer: MS $m / z$ (rel. int., \%) $200\left(\mathrm{M}^{+}, 13.8\right), 182$ (28.0), 144 (72.8); 99 (82.4), 43 (100.0); $E$ isomer: $201\left(\mathrm{M}^{+}+1,7.6\right), 181$ (30.3), 144 (96.1); 99 (42.6), 43 (100.0); Markovnikov adduct: $201\left(\mathrm{M}^{+}+1,6.7\right), 183$ (23.9), 144 (88.7), 43 (100.0). HRMS (ESI): $m / z$ Calcd for $\mathrm{C}_{9} \mathrm{H}_{9} \mathrm{ClOS}[\mathrm{M}+\mathrm{H}]^{+}: 222.9960$. Found: 223.0980 .

2-Methyl-4-(phenylthio)but-3-en-2-ol (3c). ${ }^{1} \mathrm{H} \mathrm{NMR}\left(400 \mathrm{MHz}, \mathrm{CDCl}_{3}\right) \delta Z$ isomer: 7.22-7.45 $(\mathrm{m}, 5 \mathrm{H}) ; 6.19(\mathrm{~d}, J 10.61 \mathrm{H}) ; 5.80(\mathrm{~d}, J 10.6,1 \mathrm{H}) ; 1.85(\operatorname{broad} \mathrm{s}, 1 \mathrm{H}) ; 1.45(\mathrm{~s}, 6 \mathrm{H}) ;{ }^{13} \mathrm{C}$ NMR $\left(100 \mathrm{MHz}, \mathrm{CDCl}_{3}\right) \delta 18.4,29.6,54.3,123.0,126.7,128.9,129.5,133.2,135.1$; $E$ isomer: $7.22-$ $7.45(\mathrm{~m}, 5 \mathrm{H}) ; 6.41(\mathrm{~d}, J 15.01 \mathrm{H}) ; 5.99(\mathrm{~d}, J 15.0,1 \mathrm{H}) ; 1.78(\operatorname{broad} \mathrm{s}, 1 \mathrm{H}) ; 1.35(\mathrm{~s}, 6 \mathrm{H}) ;{ }^{13} \mathrm{C}$ NMR (100 MHz, $\left.\mathrm{CDCl}_{3}\right) \delta 18.4,29.8,72.0,116.0,123.2,126.8,129.0,129.7,134.5$; Markovnikov adduct: ${ }^{7,26} 7.26-7.37(\mathrm{~m}, 4 \mathrm{H}) ; 5.45(\mathrm{~s}, 1 \mathrm{H}) ; 4.72(\mathrm{~s}, 1 \mathrm{H}) ; 2.21$ (broad s, 1H); 1.51 (s, 6H); MS m/z (rel. int., \%) $Z$ isomer: 194 ( $\left.\mathrm{M}^{+}, 11.9\right), 135$ (100.0), 77 (16.4); $E$ isomer: 193 $\left(\mathrm{M}^{+}\right.$- 1, 2.3), 110 (24.3), 82 (100.0); Markovnikov adduct: 194 (5.8), 110 (100.0), 77 (4.3). HRMS (ESI): $m / z$ Calcd for $\mathrm{C}_{11} \mathrm{H}_{14} \mathrm{OS}[\mathrm{M}+\mathrm{Na}]^{+}, 217.0663$. Found: 217.0661.

1-(1-Phenylsulfanylvinyl)cyclohexanol (3d). ${ }^{1} \mathrm{H}$ NMR (400 $\left.\mathrm{MHz}, \mathrm{CDCl}_{3}\right) \delta Z$ isomer: 7.16$7.37(\mathrm{~m}, 5 \mathrm{H}) ; 6.22(\mathrm{~d}, J 10.0,1 \mathrm{H}) ; 5.77(\mathrm{~d}, J 10.0,1 \mathrm{H}) ; 2.09$ (broad s, 1H), 1.20-1.80 (m, 10H); ${ }^{13} \mathrm{C} \mathrm{NMR}\left(50 \mathrm{MHz}, \mathrm{CDCl}_{3}\right) \delta 23.0,25.0,39.7,72.2,123.6,126.7,128.9,129.2,135.4,136.2 ; E$ isomer: 7.16-7.37 (m, 5H); $6.44(\mathrm{~d}, J 15.2,1 \mathrm{H}) ; 6.00(\mathrm{~d}, J 15.2,1 \mathrm{H}) ; 2.47$ (broad s, 1H); 1.20$1.80(\mathrm{~m}, 10 \mathrm{H}) ;{ }^{13} \mathrm{C} \mathrm{NMR}\left(50 \mathrm{MHz}, \mathrm{CDCl}_{3}\right) \delta 21.9,25.3,37.8,72.0,121.2,126.5,128.9,129.2$, 129.5, 140.6. Markovnikov adduct: ${ }^{26,27} 7.16-7.37$ (m, 5H); 5.48 (s, 1H); $4.76(\mathrm{~s}, 1 \mathrm{H}) ; 2.47$ (broad $\mathrm{s}, 1 \mathrm{H})$; 1.20-1.80 (m, 10H); MS m/z (rel. int., \%) $Z$ isomer: $234\left(\mathrm{M}^{+}, 34.1\right), 216$ (50.4), 139 (79.6), 79 (100.0); $E$ isomer: 234 (M+, 43.3$), 216$ (71.9), 139 (93.2), 79 (100.0); Markovnikov adduct: 234 ( $\mathrm{M}^{+}$34.6), 135 (100.0), 91 (55.5). HRMS (ESI): $m / z$ Calcd for $\mathrm{C}_{14} \mathrm{H}_{18} \mathrm{OS}[\mathrm{M}+\mathrm{Na}]^{+}$: 257.0976; Found: 257.0973.

1-[1-(4-Chlorophenyl)sulfanylvinyl]cyclohexanol (3e). ${ }^{1} \mathrm{H} \mathrm{NMR}\left(400 \mathrm{MHz}, \mathrm{CDCl}_{3}\right) \delta Z$ isomer: 7.25-7.26 (m, 4H); $6.15(\mathrm{~d}, J 10.2,1 \mathrm{H}) ; 5.79(\mathrm{~d}, J 10.2,1 \mathrm{H}) ; 2.16($ broad s, $1 \mathrm{H}) ; 1.25-$ $2.16(\mathrm{~m}, 10 \mathrm{H}) ;{ }^{13} \mathrm{C} \mathrm{NMR}\left(100 \mathrm{MHz}, \mathrm{CDCl}_{3}\right) \delta 22.2,24.3,25.2,73.0,116.6,128.9,129.3,130.2$, 
135.2, 136.5; $E$ isomer: 7.25-7.26 (m, 4H); $6.40(\mathrm{~d}, J$ 15.2, 1H); $6.02(\mathrm{~d}, J$ 15.2, 1H); 2.13 (broad $\mathrm{s}, 1 \mathrm{H}) ; 1.25-2.16(\mathrm{~m}, 10 \mathrm{H}) ;{ }^{13} \mathrm{C} \mathrm{NMR}\left(100 \mathrm{MHz}, \mathrm{CDCl}_{3}\right) \delta 21.9,23.0,25.0,72.0,123.1,129.0$, 129.8, 130.7, 134.4, 138.4; Markovnikov adduct: 7.25-7.26 (m, 4H); $5.52(\mathrm{~s}, 1 \mathrm{H}) ; 4.78(\mathrm{~s}, 1 \mathrm{H})$; 1.90 (broad s, 1H); 1.25-2.16 (m, 10H). MS m/z (rel. int., \%) $\mathrm{Z}$ isomer: $270\left(\mathrm{M}^{+}+2,9.3\right), 268$ $\left(\mathrm{M}^{+}, 23.0\right), 139$ (64.0), 79 (100.0); $E$ isomer: $270\left(\mathrm{M}^{+}+2,8.2\right), 268\left(\mathrm{M}^{+}, 21.6\right), 139$ (3.7), 79 (100.0); Markovnikov adduct: $270\left(\mathrm{M}^{+}+2,10.5\right), 268\left(\mathrm{M}^{+}, 27.8\right), 170$ (42.7), 135 (100.0), 81 (91.2). HRMS (ESI): $m / z$ Calcd for $\mathrm{C}_{14} \mathrm{H}_{17} \mathrm{ClOS}[\mathrm{M}+\mathrm{Na}]^{+}: 291.0586$; Found: 291.0572.

4-(Phenylthio)but-3-en-1-ol (3f). $\left.{ }^{28}{ }^{1} \mathrm{H} \mathrm{NMR} \mathrm{(400} \mathrm{MHz,} \mathrm{CDCl}_{3}\right) \delta Z$ isomer: 7.15-7.43 (m, 5H); $6.31(\mathrm{dt}, J 9.6$ and $1.6,1 \mathrm{H}) ; 5.83(\mathrm{dt}, J 9.6$ and $6.4,1 \mathrm{H}) ; 3.65(\mathrm{t}, J 6.4,2 \mathrm{H}) ; 2.56$ (broad s, $1 \mathrm{H})$; 2.47-2.53 (m, 2H); $E$ isomer: 7.15-7.43 (m, 5H); $6.24(\mathrm{dt}, J 15.2$ and 1.6, $1 \mathrm{H}) ; 5.90$ (dt, $J 15.2$ and $6.8,1 \mathrm{H}) ; 3.69(\mathrm{t}, J 6.8,2 \mathrm{H}) ; 2.56($ broad s, $1 \mathrm{H}) ; 2.35-2.41(\mathrm{~m}, 2 \mathrm{H})$; Markovnikov adduct: ${ }^{7}$ 7.15-7.43 (m, 5H); $5.23(\mathrm{~s}, 1 \mathrm{H}) ; 4.99(\mathrm{~s}, 1 \mathrm{H}) ; 3.76(\mathrm{t}, J$ 6.4, 2H); $2.56($ broad s, 1H); 2.47-2.53 (m, 2H). MS m/z (rel. int., \%) $Z$ isomer: $180\left(\mathrm{M}^{+}, 49.1\right), 149$ (100.0), 116 (83.0); $E$ isomer: 180 $\left(\mathrm{M}^{+}\right.$, 49.1), 149 (100.0), 116 (83.0); Markovnikov adduct: $180\left(\mathrm{M}^{+}, 12.9\right), 135$ (84.7), 110 (100.0).

4-(4-Chlorophenylthio)but-3-en-1-ol (3g). ${ }^{1} \mathrm{H}$ NMR $\left(200 \mathrm{MHz}, \mathrm{CDCl}_{3}\right) \delta Z$ isomer: 7.24-7.26 $(\mathrm{m}, 4 \mathrm{H}) ; 6.28(\mathrm{dt}, J 9.6$ and $1.0,1 \mathrm{H}) ; 5.88(\mathrm{dt}, J 9.6$ and $6.6,1 \mathrm{H}) ; 3.71(\mathrm{t}, J 6.6,2 \mathrm{H}) ; 2.36-2.57$ $(\mathrm{m}, 2 \mathrm{H}) ; 1.96$ (broad s, $1 \mathrm{H}) ; E$ isomer: 7.24-7.26 (m, 4H); $6.22(\mathrm{dt}, J 15.2$ and 1.2, 1H); 5.93 (dt, $J 15.2$ and $6.6,1 \mathrm{H}) ; 3.71(\mathrm{t}, J 6.6,2 \mathrm{H}) ; 2.36-2.57(\mathrm{~m}, 2 \mathrm{H}) ; 1.96$ (broad s, 1H); Markovnikov adduct: $7.32-7.34(\mathrm{~m}, 4 \mathrm{H}) ; 5.27(\mathrm{~s}, 1 \mathrm{H}) ; 5.02(\mathrm{~s}, 1 \mathrm{H}) ; 3.76(\mathrm{t}, J 6.6,2 \mathrm{H}) ; 2.36-2.57(\mathrm{~m}, 2 \mathrm{H}) ; 2.03$ (broad s, $1 \mathrm{H}) .{ }^{13} \mathrm{C} \mathrm{NMR}\left(50 \mathrm{MHz}, \mathrm{CDCl}_{3}\right) \delta Z+E+$ Markovnikov adduct: 28.6, 32.3, 39.1, 59.1, $62.9,63.1,124.0,125.3,125.4,128.7,129.1,129.2,129.3,129.4,130.1,130.2,131.1,131.6$, 132.4, 134.2, 134.3, 134.4. MS $m / z$ (rel. int., \%) $Z$ isomer: $216\left(\mathrm{M}^{+}+2,26.1\right), 214\left(\mathrm{M}^{+}, 69.4\right)$, 183 (100.0), 148 (99.1); $E$ isomer: $216\left(\mathrm{M}^{+}+2,26.1\right), 214\left(\mathrm{M}^{+}, 69.4\right), 183$ (100.0), 148 (99.1); Markovnikov adduct: $214\left(\mathrm{M}^{+}, 33.5\right), 144$ (100.0), 109 (60.2). HRMS (ESI): $m / z$ Calcd for $\mathrm{C}_{10} \mathrm{H}_{11} \mathrm{ClOS}[\mathrm{M}+\mathrm{Na}]^{+}: 237.0117$; Found: 237.0117.

Hept-1-enyl(phenyl)sulfide (3h). ${ }^{1} \mathrm{H}$ NMR (200 $\left.\mathrm{MHz} \mathrm{CDCl}_{3}\right) \delta Z$ isomer: 7.13-7.50 (m, 5H); $6.18(\mathrm{~d}, J 9.2,1 \mathrm{H}) ; 5.82(\mathrm{dt}, J 9.2$ and $6.4,1 \mathrm{H}) ; 2.10-2.30(\mathrm{~m}, 2 \mathrm{H}) ; 1.30-1.47(\mathrm{~m}, 6 \mathrm{H}) ; 0.90(\mathrm{t}, J$ 6.4, 3H); ${ }^{13} \mathrm{C} \mathrm{NMR}\left(50 \mathrm{MHz}, \mathrm{CDCl}_{3}\right) \delta 14.0,22.5,29.1,31.4,33.0,126.0,127.1,128.7,128.9$, 129.1, 137.8; $E$ isomer: 7.13-7.50 (m, 5H); $6.13(\mathrm{~d}, J 15.0,1 \mathrm{H}) ; 5.99(\mathrm{dt}, J 15.0$ and $6.2,1 \mathrm{H})$; 2.10-2.30 (m, 2H); 1.30-1.47 (m, 6H); $\left.0.90(\mathrm{t}, J 6.2,3 \mathrm{H}) ;{ }^{13} \mathrm{C} \mathrm{NMR} \mathrm{(50} \mathrm{MHz,} \mathrm{CDCl}_{3}\right) \delta 14.0$, $22.4,28.7,31.3,33.0,126.0,127.5,128.4,128.9,129.0,132.7$. MS $m / z$ (rel. int., $\%$ ) $Z$ isomer: $206\left(\mathrm{M}^{+}, 63.0\right), 149$ (96.6), 110 (100.0), 55 (81.3); $E$ isomer: 206 (M+ 66.2), 149 (100.0), 110 (93.7), 55 (77.6). HRMS (ESI): $m / z$ Calcd for $\mathrm{C}_{13} \mathrm{H}_{19} \mathrm{~S}[\mathrm{M}+\mathrm{H}]^{+}:$207.1207; Found: 207.1202.

(4-Chlorophenyl)(hept-1-enyl)sulfide (3i). $\left.{ }^{1} \mathrm{H} \mathrm{NMR} \mathrm{(400} \mathrm{MHz,} \mathrm{CDCl}_{3}\right) \delta Z$ isomer: 7.20-7.26 $(\mathrm{m}, 4 \mathrm{H}) ; 6.10(\mathrm{dt}, J 10.4$ and $1.2,1 \mathrm{H}) ; 5.84(\mathrm{dt}, J 10.4$ and $7.2,1 \mathrm{H}) ; 2.25(\mathrm{q}, J 7.2,2 \mathrm{H}) ; 1.31$ $1.43(\mathrm{~m}, 6 \mathrm{H}) ; 0.92(\mathrm{t}, J$ 7.2, 3H); $E$ isomer: 7.20-7.26 (m, 4H); $6.07(\mathrm{~d}, J 15.2,1 \mathrm{H}) ; 6.0(\mathrm{dt}, J$ 15.2 and 7.2, $1 \mathrm{H}) ; 2.17(\mathrm{q}, J 7.2,2 \mathrm{H}) ; 1.31-1.43(\mathrm{~m}, 6 \mathrm{H}) ; 0.91(\mathrm{t}, J 7.2,3 \mathrm{H}) ;{ }^{13} \mathrm{C}$ NMR $(100$ $\left.\mathrm{MHz}, \mathrm{CDCl}_{3}\right) \delta \mathrm{Z}+\mathrm{E}: 14.0,22.4,22.43,28.5,28.6,29.0,31.2,31.3,33.0,120.0,121.8,128.9$, $129.0,129.1,129.2,129.4,129.7,133.5,134.0,134.6,135.0,138.8$. MS m/z (rel. int., $\%) Z$ 
isomer: $240\left(\mathrm{M}^{+}, 43.5\right), 183$ (49.7), 55 (100.0); $E$ isomer: $242\left(\mathrm{M}^{+}+2,16.0\right), 240\left(\mathrm{M}^{+}, 42.3\right)$, 183 (46.5), 148 (75.9), 55 (100.0). HRMS (ESI): $\mathrm{m} / z$ Calcd for $\mathrm{C}_{13} \mathrm{H}_{17} \mathrm{ClS}[\mathrm{M}+\mathrm{H}]^{+}: 263.0637$; Found: 262.9876.

\section{Acknowledgements}

This project was funded by CNPq, FINEP, FAPERGS/PRONEX 10/0005-1 and CAPES. Prof. Lopes, N. P., from FCFRP-USP, is thanked for the HRMS analyses.

\section{References}

1. (a) Marcantoni, E.; Massaccesi, M.; Petrini, M. J. Org. Chem. 2000, 65, 4553; (b) Kuligowski, C.; Bezzenine-Lafollée, S.; Chaume, G.; Mahuteau, J.; Barrière, J.-C.; Bacqué, E.; Pancrazi, A.; Ardisson, J. J. Org. Chem. 2002, 67, 4565.

2. Lan, H. W; Cooke, P. A.; Pattenden, G.; Bandaranayake, W. M.; Wickramasinghe, W. A. J. Chem. Soc., Perkin Trans. 1 1999, 847.

3. For the synthetic utility of vinyl sulfides, see, for example: (a) Aucagne, V.; Lorin, C.; Tatibouët, A.; Rollin, P. Tetrahedron Lett. 2005, 46, 4349. (b) Muraoka, N.; Mineno, M.; Itami, K.; Yoshida, J.-I. J. Org. Chem. 2005, 70, 6933. (c) Woodland, C. A.; Crawley, G. C.; Hartley, R. C. Tetrahedron Lett. 2004, 45, 1227. (d) McReynolds, M. D.; Dougherty, J. M.; Hanson, P. R. Chem. Rev. 2004, 104, 2239. (e) Oae, S. Organic Sulfur Chemistry: Structure and Mechanism; CRC Press: Boca Raton, FL, 1991; Cremlyn, R. J. An Introduction to Organosulfur Chemistry; Wiley \& Sons: New York, 1996.

4. (a) Kondo, T.; Mitsudo, T. Chem. Rev. 2000, 100, 3205. (b) Cao, C.; Fraser, L. R.; Love, J. A. J. Am. Chem. Soc. 2005, 127, 17614. (c) Weiss, C. J.; Wobser, S. D.; Marks, T. J. J. Am. Chem. Soc. 2009, 131, 2062. (d) Ogawa, A.; Ikeda, T.; Kimura, K.; Hirao, T. J. Am. Chem. Soc. 1999, 121, 5108. (e) Malyshev, D. A.; Scott, N. M.; Marion, N.; Stevens, E. D.; Ananikov, V. P.; Beletskaya, I. P.; Nolan, S. P. Organometallics 2006, $25,4462$.

5. (a) Waters, M. S.; Cowen, J. A.; McWilliams, J. C.; Maligres, P. E.; Askin, D. Tetrahedron Lett. 2000, 41, 141. (b) Dabdoub, M. J.; Dabdoub, V. B.; Lenardão, E. J.; Hurtado, G. R.; Barbosa, S. L.; Guerrero Jr., P. G.; Nazário, C. E. D.; Viana, L. H.; Santana, A. S.; Baroni, A. C. M. Synlett 2009, 986. (c) Wadsworth, D. H.; Detty, M. R. J. Org. Chem. 1980, 45, 4611.

6. Manarin, F.; Roehrs, J. A.; Prigol, M.; Alves, D.; Nogueira, C. W.; Zeni, G. Tetrahedron Lett. 2007, 48, 4805.

7. Ananikov, V. P.; Orlov, N. V.; Beletskaya, I. P. Organometallics 2006, 25, 1970.

8. Corma, A.; González-Arellano, C.; Iglesias, M.; Sánchez, F. Appl. Catal. A: Gen. 2010, 375, 49. 
9. Banerjee, S.; Das, J.; Santra, S. Tetrahedron Lett. 2009, 50, 124.

10. Sridhar, R.; Surendra, K.; Krishnaveni, N. S.; Srinivas, B.; Rao, K. R. Synlett 2006, 3495.

11. Schneider, C. C.; Godoi, B.; Prigol, M.; Nogueira, C. W.; Zeni, G. Organometallics 2007, 26, 4252.

12. Basu, B.; Das, P.; Das, S. Curr. Org. Chem. 2008, 12, 141; Blass, B. E. Tetrahedron 2002, $58,9301$.

13. (a) Handy, S. T. Chem. Eur. J. 2003, 9, 2938. (b) Leitner, W. Green Chem. 2007, 9, 923; (c) Horváth, I. T. Green Chem. 2008, 10, 1024. (d) Giovanni, I.; Silke, H.; Dieter, L.; Burkhard, K. Green Chem. 2006, 8, 1051. (e) Clark, J. H. Green Chem. 1999, 1, 1 and references cited therein.

14. Nelson, W. M. Green Solvents for Chemistry: Perspectives and Practice, Oxford University Press: Oxford, 2003.

15. Silveira, C. C.; Mendes, S. R.; Líbero, F. M.; Lenardão, E. J.; Perin, G. Tetrahedron Lett. 2009, 50, 6060 .

16. (a) Lenardão, E. J.; Trecha, D. O.; Ferreira, P. C.; Jacob, R. G.; Perin, G. J. Braz. Chem. Soc. 2009, 20, 93. (b) Lenardão, E. J.; Silva, M. S.; Sachini, M.; Lara, R. G.; Jacob, R. G.; Perin, G. Arkivoc 2009, (xi), 221-227. (c) Perin, G.; Mello, L. G.; Radatz, C. S.; Savegnago, L.; Alves, D.; Jacob, R. G.; Lenardão, E. J. Tetrahedron Lett. 2010, 51 , 4354.

17. Wolfson, A.; Dlugy, C. Chem. Pap. 2007, 61, 228.

18. Wolfson, A.; Litvak, G.; Dlugy, C. Shotland, Y; Tavor, D. Ind. Crops Prod. 2009, $30,78$.

19. Wolfson, A.; Dlugy, C.; Shotland, Y. Environ. Chem. Lett. 2007, 5, 67.

20. Wolfson, A.; Dlugy, C.; Shotland, Y; Tavor, D. Tetrahedron Lett. 2009, 50, 5951.

21. (a) He, F.; Li, P.; Gu, Y.; Li, G. Green Chem. 2009, 11, 1767. (b) Karam, A.; Villandier, N.; Delample, M.; Koerkamp, C. K.; Douliez, J.-P.; Granet, R.; Krausz, P.; Barrault, J.; Jérôme, F. Chem. Eur. J. 2008, 14, 10196. (c) Gu, Y.; Barrault, J.; Jérôme, F. Adv. Synth. Catal. 2008, 350, 2007.

22. Silva, M. S.; Lara, R. G.; Marczewski, J. M.; Jacob, R. G.; Lenardão, E. J.; Perin, G. Tetrahedron Lett. 2008, 49, 1927.

23. (a) Lenardão, E. J.; Ferreira, P. C.; Jacob, R. G.; Perin, G.; Leite, F. P. L. Tetrahedron Lett. 2007, 48, 6763. (b) Lenardão, E. J.; Lara, R. G.; Silva, M. S.; Jacob, R. G.; Perin, G. Tetrahedron Lett. 2007, 48, 7668. (c) Victoria, F. N.; Radatz, C. S.; Sachini, M.; Jacob, R. G.; Perin, G.; da Silva, W. P.; Lenardão, E. J. Tetrahedron Lett. 2009, 50, 6761.

24. Wang, S.-X.; Li, J.-T.; Yang, W.-Z.; Li, T.-S. Ultrason. Sonochem. 2002, 9, 159.

25. Ritter, R. H.; Cohen, T. J. Am. Chem. Soc. 1986, 108, 3718.

26. Kuniyasu, H.; Ogawa, A.; Sato, K.-I.; Ryu, I.; Kambe, N.; Sonoda, N. J. Am. Chem. Soc. 1992, 114, 5902.

27. Yus, M.; Gutiérrez, A.; Foubelo, F. Tetrahedron 2001, 57, 4411.

28. Ihara, M.; Katsumata, A.; Setsu, F.; Tokunaga, Y.; Fukumoto, K. J. Org. Chem. 1996, 61, 677. 